Geology - Mineralogy

This document consists of 22 pages. Series A

\author{
UNITED STATES DEPARTMENT OF THE INTERIOR \\ GEOLOGICAL SURVEY
}

\title{
RECONNAISSANCE FOR RADIOACTIVE DEPOSITS IN THE \\ RUBY-POORMAN DISTRICT, RUBY QUADRANGLE
}

CENTRAL ALASKA， 1949*

\section{By}

Max G. White and John M. Stevens

February 1953

Trace Elements Investigations Report 192

This preliminary report is distributed without editorial and technical review for conformity with official standards and nomenclature. It is not for pub-

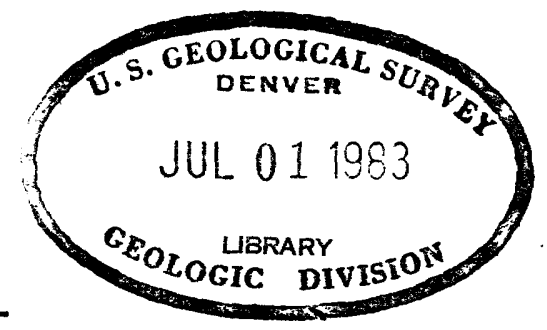
lic inspection or quotation.

*This report concerns work done on behalf of the Division of Raw Materials of the U. S. Atomic Energy Commission. 
-

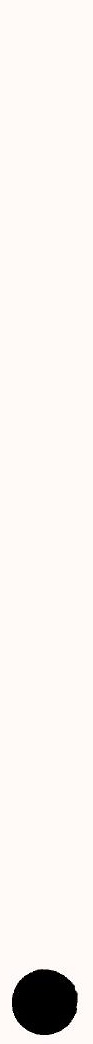


USGS - TEI Report 192

GEOLOGY - MINERALOGY

Distribution (Series A)

No. of copies

American Cyanamid Company, Winchester ............ 1

Argonne National Laboratory . . . . . . . . . . . . . . 1

Atomic Energy Commission, Washington ............ 2

Battelle Memorial Institute, Columbus .............. 1

Carbide and Carbon Chemicals Company, Y-12 Area.......... 1

Division of Raw Materials, Grants ............... 1

Division of Raw Materials, Denver ............... 1

Division of Raw Materials; Hot Springs ...............

Division of Raw Materials, New York ..............6

Division of Raw Materials, Salt Lake City ............. 1

Division of Raw Materials, Richfield ............... 1

Division of Raw Materials, Butte ............... 1

Division of Raw Materials, Washington .............. 3

Dow Chemical Company, Pittsburg . . . . . . . . . . . . 1

Exploration Division, Grand Junction Operations Office .......

Grand Jünction Operations Office . . . . . . . . . . . . 1

Technical Information Service; Oak Ridge ............6

Tennessee Valley Aüthority, Wilson Dam ............. 1

Terr. Dept. Mines, Juneau (P. H. Holdsworth) . . . . . . . . . I

Terr. Dept. Mines, Ketchikan (A. E. Glover) ............ I

Terr. Dept. Mines, College (L. L. Patton) . . . . . . . . . 1

Terr. Dept. Mines, Nome (D. Jones)............... 1

U. S. Geolögical Survey:

Mineral Deposits Branch, Washington ............... 1

Geochemistry and Petrology Branch, Washington ..........

Geophysics Branch, Washington. ................ 1

Alaskan Geology Branch, Washington. ............ 8

G. O. Gates, San Francisco................. 2

L. H. Saarela, Anchorage ................. 1

C. L. Sainsbury, Juneau ... . . . . . . . . . . . 1

R. M. Chapman, Fairbanks ................ 1

V. E. McKelvey, Washington ................ 1

L. R. Page, Denver .................... 1

R. P. Fischer, Grand Junction ................. . 1

A. E. Weissenborn, Spokane ................. 1

TEPCO, Washington ................... 5

(Including master) 
-

0

0 


\section{CONTENTS}

Abstract .......................... 4

Introduction ......................... 5

Geology............................. . . 7

Bedrock ......................... 7

Alluvium ....................... 8

Mineral deposits ..........................

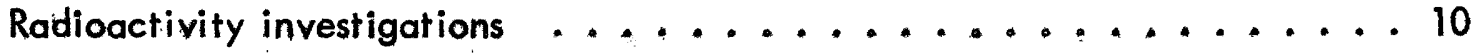

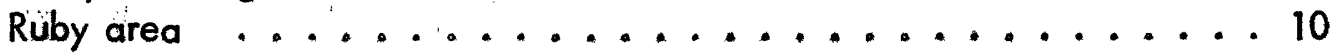

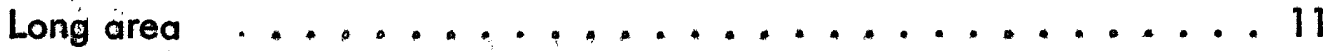

Granite on Birch and Straight Creeks ........... 13

Granite on upper Flint Creek ............. 16

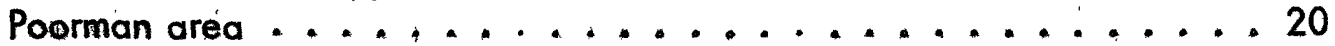

Summary and conclusions ..................... 21

Literature cited . . . . . . . . . . . . . . . . . . 22

\section{ILLUSTRATIONS}

Figure 1. Sketch map of the Ruby-Poorman district, Alaska, showing locations of Birch Creek and upper Flint Creeks .......6 6

2. Geologic sketch map of Birch Creek, Ruby-Poorman district, Alaska................... 12

3. Geologic sketch map of upper Flint Creek, Ruby-Poorman district, Alaska .................. 14

\section{TABLES}

Table 1. Data on samples from the vicinity of the granite on Birch and Straight Creeks, $1949 \ldots \ldots \ldots$

2. Data on samples from the vicinity of the granite on upper

Flint Creek and Monument Creeks, $1949 \ldots . . . . .17$ 
-

- 


\title{
RECONNAISSANCE FOR RADIOACTIVE DEPOSITS IN THE \\ RUBY-POORMAN DISTRICT, RUBY QUADRANGLE, CENTRAL ALASKA, 1949
}

By Max G. White and John M. Stevens

\begin{abstract}
Reconnaissance for radioactive deposits in the Ruby-Poorman district, Ruby quadrangle, central Alaska during July 1949 showed that two small bodies of granite in the Long area, about 30 miles south of Ruby, contain an average of 0.005 percent equivalent uranium. This radioactivity is due chiefly to a uraniferous thorium silicate, tentatively identified as uranothorite, which is disseminated in the granite. Other minerals, such as sphene, allanite, and zircon, that contain radioactive elements as impurities, however, also contribute to the total radioactivity of the granite: The uranothorite(?) contains about 57 percent thorium and 8 percent uranium.

Search for the bedrock source of a radioactive mineral of the spinel group which occurs in placers on upper Solomon Creek in the Poorman area was unsuccessful. Radiometric traversing indicated no anomalous radiation at a silver-bearing galena deposit on New York Creek in the Ruby area.

Although it is believed that there is little possibility of commercial deposits of uranium in the Ruby-Poorman district, it should be noted that the heavy cover of vegetation and alluvium prevents complete coverage of the district by radiometric surveying,
\end{abstract}


-

-

- 


\section{INTRODUCTION}

The Ruby-Poorman district (fig. 1) lies just south of the Yukon River mainly along the divide between the Innoko and Nowitna Rivers in central Alaska, approximately 230 miles west of Fairbanks. Ruby, Long, and Poorman are the only settlements in the area. Ruby (population .175) is located on the Yukon River and is the point of entry for supplies to the mines in the district. Long is 28 miles south of Ruby and is the center of most of the mining activity in the district. Poorman is about 25 miles south of Long and is located in the headwaters of the Innoko River drainage. Long and Poorman are now virtually abandoned and have a combined population of not more than 8 people. The Alaska Road Commission maintains a single-lane truck road from Ruby to a point near Monument Creek (fig. 1). Formerly, this road extended to Poorman, but maintenance on this stretch of road was abandoned a few years ago and it is now impassable even to tractors.

Study of concentrates in the Geological Survey's Alaskan Geology Branch collections showed the presence of radioactive minerals in placers on the upper part of Solomon Creek near Poorman and near two small granite intrusives in the vicinity of Long. The occurrence of these radioactive minerals, coupled with the facts that tin and bismuth are also known in the placers, and a silver-bearing galena deposit is located about 12 miles south of Ruby indicated that the district might be favorable for the occurrence of uraniferous lodes. The party conducting the reconnaissance consisted of M. G. White and J. M. Stevens, geologists, and Egil Salveson and R. D. Olson, camp assistants. It worked in the area during the month of July 1949. The accessibility of the area to jeep travel was of considerable aid to the party. It is estimated that without a jeep for travel the operation would have taken the entire 


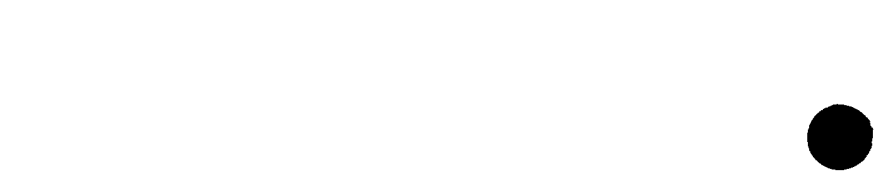

-

- 


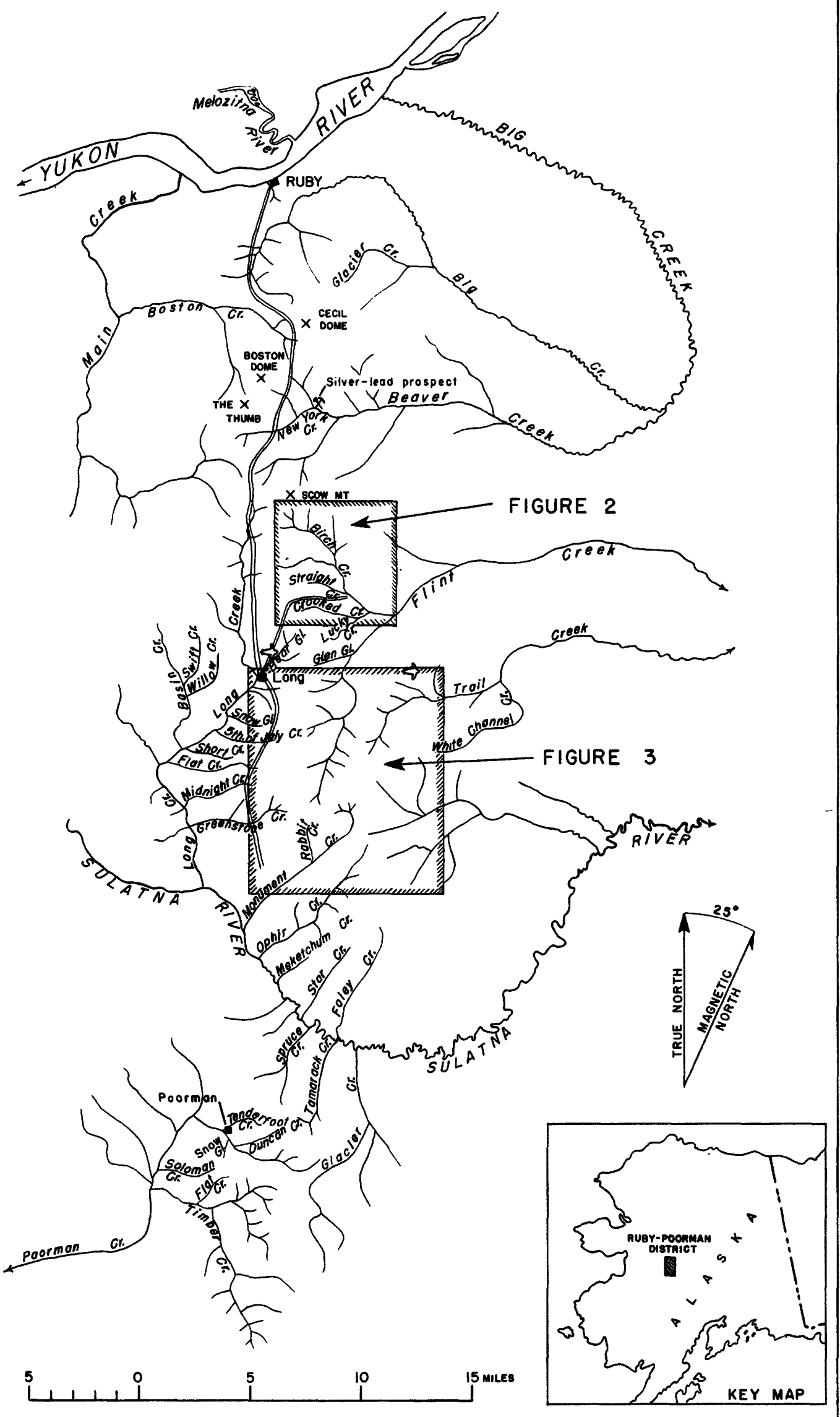

SKETCH MAP OF THE RUBY-POORMAN DISTRICT, ALASKA 
0

0

0 
season of three months rather than the one month actually used. This work was done on behalf of the Division of Raw Materials of the U. S. Atomic Energy Commission.

\section{GEOLOGY}

The geology of the Ruby-Poorman district is known only on a reconnaissance scale chiefly as a result of investigations by Eakin (1914, pp. 20-27), Mertie and Harrington (1924, pp. 12-74), and Mertie (1936, pp. 130-143). The mantle of residual soil covering most of the upper slopes and tops of all the hills; the depth of alluvium covering all the lower slopes and stream valleys; and the blanket of moss, low brush, and timber growth covering all but the highest hills make any geologic investigation both difficult and time-consuming. Outcrops are rare, talus slides are uncommon, and float rock is found usually only by digging through the moss into the residual soil mantle.

\section{Bedrock}

The major part of the country rock in the Ruby-Poorman district consists of a metamorphic rock complex including schist, phyllite, slate, greenstone, quartzite, chert, and limestone of Paleozoic age and possibly older. From this complex it has been possible to separate out and map separately the following formations: a recrystallized limestone of unknown age; Devonian rocks consisting mainly of limestone; and a group of rocks that include greenstone, tuff, and chert. Granite bodies i cropping out in the headwaters of Flint Creek and on Birch Creek, are tentatively classified as Mesozoic. The youngest rocks in the district are believed to be some soda-granite dikes of possible Eocene age that occur in the vicinity of Poorman, and below Ruby on the banks of the Yukon River. 
-

•

0 


\section{Alluvium}

Elevations within the district range from less than 400 feet above sea level at Ruby to somewhat over 1,800 feet on some of the rounded hills south of Ruby. The average elevation is probably between 1,300 and 1,400 feet. Alluvial deposits consisting mainly of Pleistocene silt with some gravel fill nearly all the stream valleys almost to their heads and in places occur as high as 1,200 feet. Faintly outlined terraces are found at elevations of 1,000 feet and higher along some of the bedrock slopes and on many of the ridges. It is of some significance that the only rock outcrops seen below that elevation are along stream cuts of Recent age. Essentially all of the bedrock float found was in frost-heave mounds thrown up through the alluvial mantle. Eakin (1916, p. 55) in discussing the origin of these alluvial deposits, widespread in this region of Alaska, states:

"The character of the silts indicates deposition in quiet water, the distribution and form of the gravel terraces point to origin by beach action. As there are ofher corroborative lines of evidence pointing to the extensive inundation of the low-lying parts of the region, probably during and following the period of maximum glaciation in interior Alaska, the silts are interpreted as the deposits made by the debris-laden glacial waters and the high-lying gravel terraces as largely the product of beach action on the shores of lakes that are now extinct. There are also more extensive high-level gravel deposits that are probably of fluvial origin, representing deltas built out into the margins of the ancient lakes by glacial and other streams."

According to Maddren (1910, p. 68) there was an interval following the glaciation when downcutting by the present streams was very rapid, leaving some of the preglacial gravel perched on the sides of the valleys as bench gravels. This gravel appears on the west side of middle Flint Creek, and on lower Birch Creek. 
-

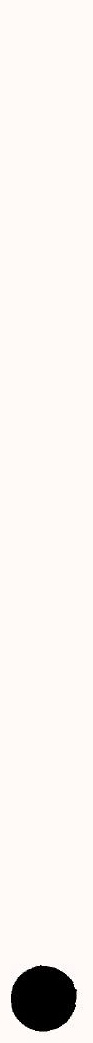




\section{MINERAL DEPOSITS}

Placer gold has been the only mineral mined profitably in the Ruby-Poorman district. Tin is abundant in many of the streams of the area, and though attempts have been made to ship some of the cassiterite concentrate to the American market, none of the attempts have been profitable. The lode source of both the tin and gold is easily surmised to be from the hills and ridges adjacent to the placer deposits. However, the residual rock and vegetal material on the ridges, and the alluvial mantle in the stream valleys so effectively mask the bedrock in the district as to make any lode prospecting too expensive and speculative an enterprise. A general description of the lode and placer deposits in the district is given in a report prepared by Mertie (1936).

Development work was done for a number of years on a silver-lead prospect on New York Creek at the head of Beaver Creek (fig. 1) in the vicinity of Ruby. Attempts to ship the ore were unprofitable, and the property was abandoned. This deposit (Brown, 1926, pp. 146, 147; Mertie, 1936, pp. 226, 227) consists of metalliferous lenticular veins as much as several feet thick which lie parallel to the cleavage of the enclosing micaceous quartz schist. The ore consists chiefly of silver-bearing galena, much cerussite and limonite, minor amounts of rhodochrosite, manganese oxides, calcite, and siderite, and traces of gold, quartz, pyrite, and ruby silver.

Bismuth occurs at two localities: one in the vicinity of Ruby, at the head of Glacier Creek (fig. 1) where a sluice-box concentrate from placer-gold mining contains 29 percent bismuth by chemical analysis; the other on lower Birch Creek in the vicinity of Long, where Mertie (1936, p. 157) reported finding native bismuth in the placer concentrates. 
-

0

0 


\section{RADIOACTIVITY INVESTIGATIONS}

The vegetal and alluvial mantle blanketing a large part of the Ruby-Poorman district effectively absorbs most of the radiation from radioactive minerals in the underlying rocks. Radiometric testing in the district, therefore, was efficient only at the few localities where bedrock is exposed, in talus, or on the portions of the ridges and upper valley slopes where the vegetation cover was not too thick to test the inderlying residuum either directly or with shallow test pits. For example, it is estimated that only about 20 percent of the road between Ruby and Monument Creeks (fig. 1) was satisfactorily tested by traversing with a jeep because of the thick vegetal and alluvial mantle. Two probes one containing six 1-by 14-inch copper-walled gamma tubes, the other with four 1- by 18-inch brass-walled gamma tubes, were attached to standard commercial models of portable survey meters for jeep and backpacking traverses.

\section{Ruby area}

Fifteen placer concentrates from the Ruby area were in the Survey's Alaskan concentrate collection before the present investigation. The creeks (fig. 1) from which these samples had been obtained, the number of samples available, and the range in equivalent uranium content of the samples from each creek are given below.

Creek

Ruby Creek

Glacier Creek

Big Creek

Cox Pup (headwater tributary of

Big Creek)
No. of Range in equivalent uranium

concentrates

2

6

2

5 content (percent)

$0.000-0.002$

$.000-.003$

$.000-.001$

$.001-.006$ 
-

-

• 
Because of the low radioactivity exhibited by these concentrates, reconnaissance in the Ruby area was limited to the radiometric traversing along the road and the testing of the silver-bearing galena lode on New York Creek (fig. 1) about 1.5 miles east of the road. The road traversing revealed no significant radioactivity anomalies nor was any significant amount of radioactive material found at the galena prospect. The maximum equivalent uranium content of check samples taken at this prospect was 0.003 percent.

\section{Long area}

A total of 47 placer concentrates from the Long area (fig. 1) were available for testing prior to the present investigation. The data on these concentrates are summarized below:

Creek

Birch Creek

Lucky Creek

Glen Gulch

Flint Creek

Trail Creek

Monument Creek

Greenstone Creek

Midnight Creek

Short Creek

Fifth of July Creek

Willow Creek

Long Creek

Bear Gulch
No. of

concentrates

13

1

1

1

1

1

3

13

2

2

1

5

$\cdot 3$
Range of equivalent uranium content (percent)

$$
\begin{array}{r}
0.000-0.013 \\
.001 \\
.006 \\
.43 \\
.000 \\
.032 \\
.001-.017 \\
.000-.002 \\
.000-.001 \\
.001 \\
.001 \\
.000-.001 \\
.000-.002
\end{array}
$$

It is apparent from this summary that the only concentrates with radioactivity of significance are from Birch, Flint, Monument, and Greenstone Creeks (fig. 1). These streams drain the small areas of granite on Birch Creek (fig. 2) and on the divide 
-

-

• 
UNITED STATES

DEPARTMENT OF THE INTERIOR

GEOLOGICAL SURVEY
TRACE ELEMENTS INVESTIGATIONS

REPORT 192 FIGURE 2

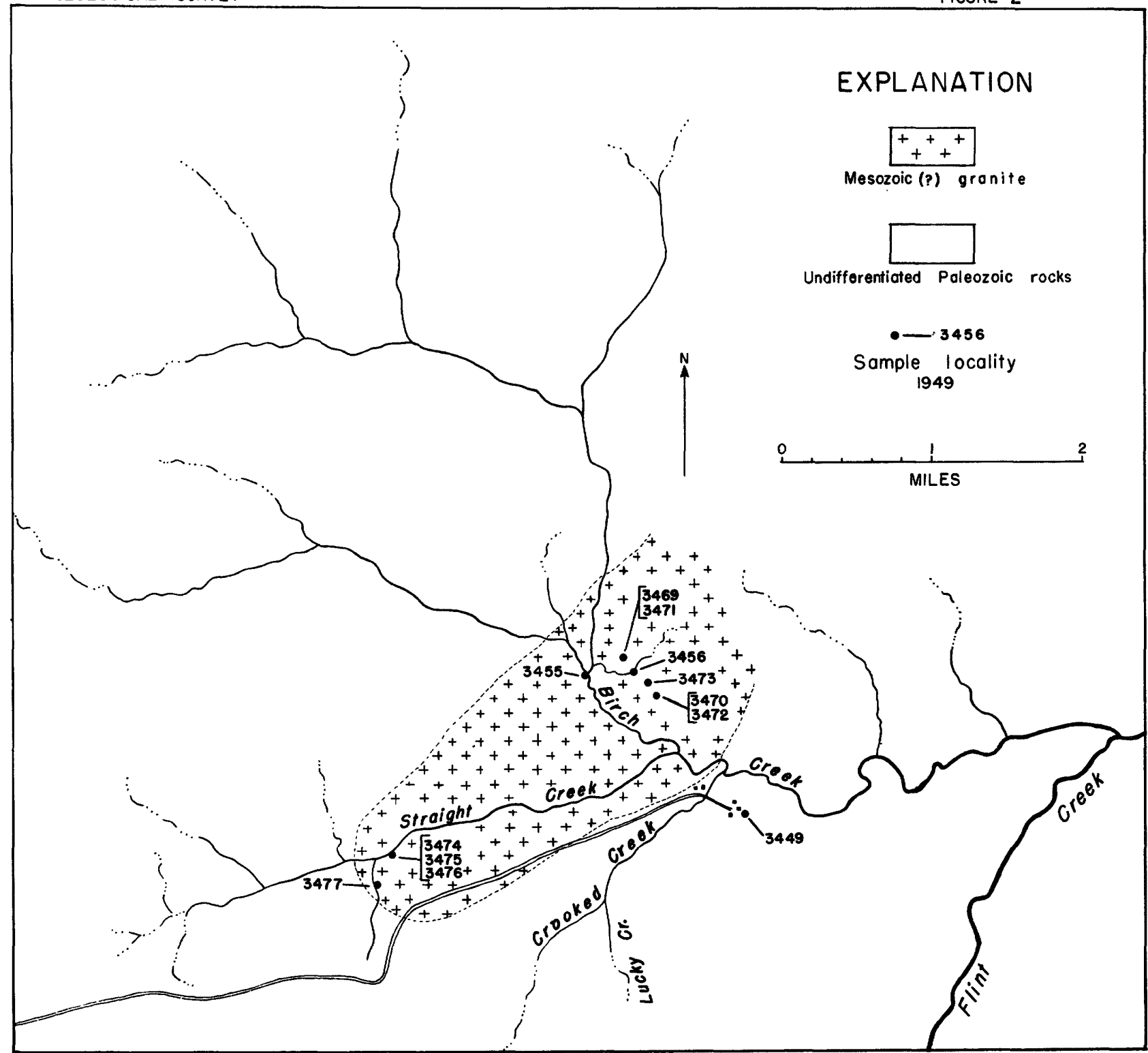

GEOLOGIC SKETCH MAP OF BIRCH CREEK, RUBY - POORMAN DISTRICT ALASKA 
-

-

• 
between Flint Creek and Monument and Greenstone Creeks (fig. 3). Consequently most of the reconnaissance in the Long area was directed toward determining whether the granite bodies were the source of the radioactive minerals in the placers, and, if so, whether any zone of concentration of radioactive minerals existed within or near the granites.

\section{Granite on Birch and Straight Creeks}

Data on the samples collected in the vicinity of the granite on Birch and Straight Creeks are given in table 1. The location of these samples are shown on figure 2. The six samples of the granite on these creeks (table 1) range from 0.003 to 0.006 percent (average 0.005 percent) in equivalent uranium content. The heavymineral fractions (those greater than 2.8 specific gravity) of these samples range from 0.007 to 0.036 percent equivalent uranium, and average 0.027 percent equivalent uranium. Similar heavy-mineral fractions of panned concentrates from placers and disintegrated granite in the vicinity of Birch Creek contain from 0.007 to 0.36 percent equivalent uranium, obviously higher because of the greater degree of concentration. Sample no. 3456, a panned placer concentrate, showed the highest equivalent uranium content, 0.36 percent, of any of the samples collected in the vicinity of Birch Creek. The radioactive elements are primarily in zircon and allanite, although the sample contains minor amounts of hematite, and traces of sphene and uranothorite(?) (see below) which are also radioactive. Although it is likely that the bulk of the radioactivity in this sample is due chiefly to thorium, all of the minerals mentioned give a positive, qualitative sodium-fluoride flux test for uranium. Other minerals in the heavy fractions of the granite and placer concentrates from the vicinity of the granite on Birch Creek are anatase, garnet, and ilmenite and a trace 
-

-

○ 
UNITED STATES

DEPARTMENT OF THE INTERIOR

TRACE ELEMENT INVESTIGATIONS

GEOLOGICAL SURVEY

REPORT 192

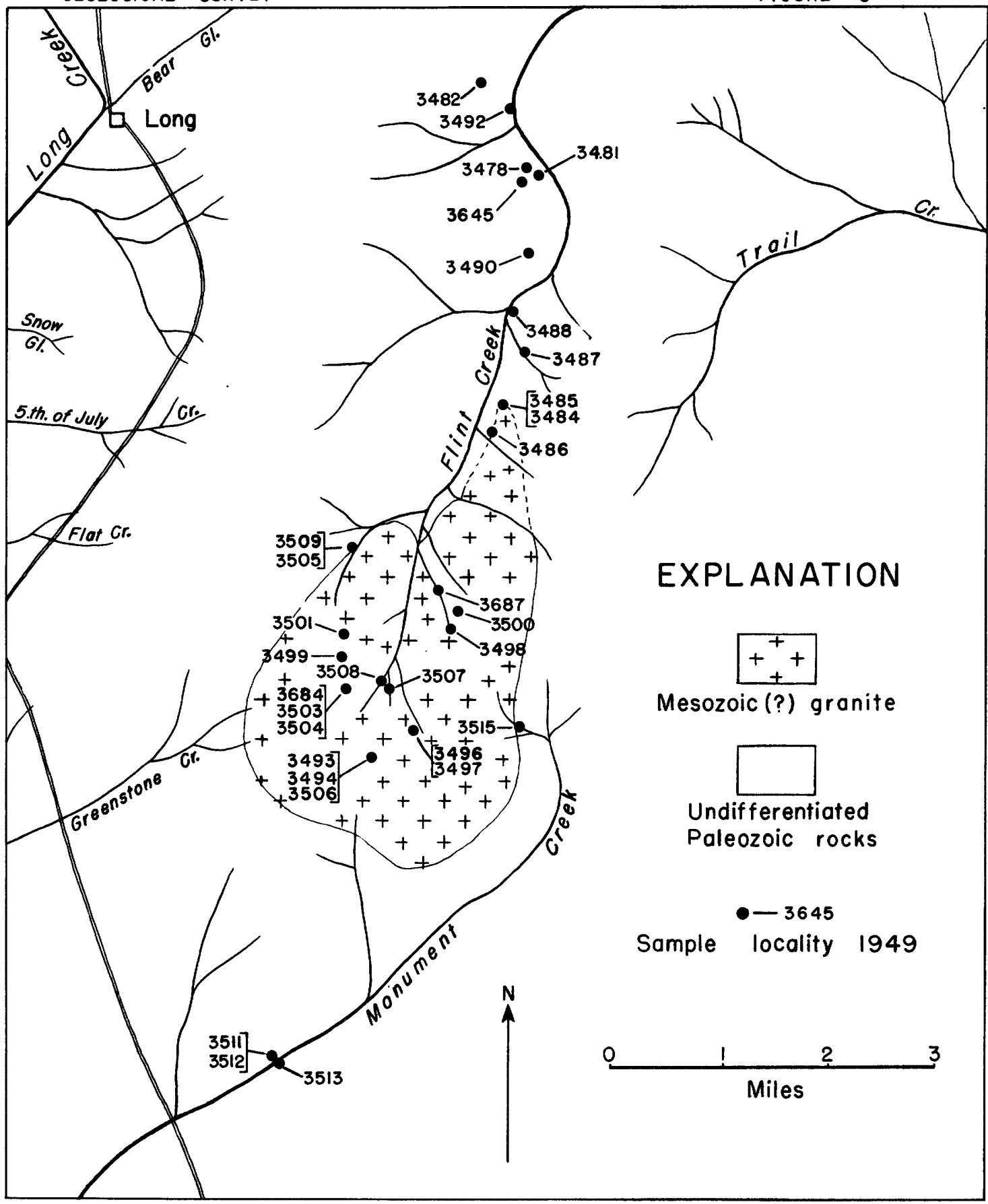

GEOLOGIC SKETCH MAP OF UPPER FLINT CREEK RUBY-POORMAN DISTRICT, ALASKA 
-

-

• 
Table 1.--Data on samples from the vicinity of the granite on Birch and Straight Creeks, 1949.

$\frac{\text { Type of sample: }}{\text { Sample no. - }}$

Crushed rock Percent eU 2/

Heavy-mineral fraction $3 /$ Percent eU Concentration ratio

Granite:

$\begin{array}{lrcr}3471-\text { Birch Creek } & 0.006 & 0.036 & 45: 1 \\ 3472-\quad \text { Do. } & .006 & .028 & 35: 1 \\ 3473-\quad \text { Do. (fine- } & .006 & .06 & 225: 1 \\ \begin{array}{l}\text { grained granitic } \\ \text { dike) }\end{array} & & & \\ 3474-\text { Straight Creek } & .003 & .009 & 13: 1 \\ 3475-\quad \text { Do. } & .006 & .013 & 17: 1 \\ 3476 \quad \text { Do. } & .005 & .015 & 30: 1\end{array}$

Panned concentrates from disintegrated granite:

$\begin{array}{llll}3469-\text { Birch Creek } & - & .30 & 15,300: 1 \\ 3470-\quad \text { Do. } & -- & .22 & 11,000: 1\end{array}$

Placer concentrates:

$\begin{array}{cccc}3449-\text { Birch Creek } & -- & .007 & \text { very high } \\ 3455-\quad \text { Do. } & -- & .024 & 2,300: 1 \\ 3456-\quad \text { Do. } & -- & .36 & 2,700: 1 \\ 3477 \text { - Straight Creek } & -- & .15 & 640: 1\end{array}$

1/ See also figure 2

2) eU - equivalent uranium

3) That greater than 2.8 specific gravity 
-

D

0 
of malachite.

\section{Granite on upper Flint Creek}

Data on the samples collected from the vicinity of the granite body on upper Flint Creek are given in table 2; the locations of the samples are shown on figure 3. The equivalent uranium content of 12 samples from this granite ranges from 0.003 to 0.008 percent and averages 0.005 percent. The range in equivalent uranium content of the heavy-mineral fractions (those greater than 2.8 specific gravity) of the 12 samples is 0.015 to 0.15 percent; the average is 0.037 percent. This average is higher than that of the granite on Birch Creek because of one heavy fraction, that of sample 3505, which contains 0.15 percent equivalent uranium. If this fraction is not considered in the range and average, the results (range $0.015-0.05$ percent equivalent uranium; average 0.026 percent equivalent uranium) are closely comparable to the range and average for the granite on Birch Creek. It is likely that this relatively greater radioactivity in the heavy fraction of sample 3505 is due to the occurrence of fewer non-radioactive minerals in proportion to the radioactive minerals rather than a greater overall content of the radioactive minerals. This is also suggested by the fact that the radioactivity of the unconcentrated granite at this point is the same as the average of the granite $(0.005$ percent equivalent uranium) a

In addition to sampling the granite itself, panned concentrates were taken of stream gravels on Flint and Monument Creeks and wash from the disintegrated granites at the head of Flint Creek. The heavy-mineral fractions of these samples show the consistently relatively higher equivalent uranium content that would be expected with the greater degree of concentration (table 2). 
-

-

○ 
Table 2.--Data on samples from the vicinity of the granite on upper Flint and Monument Creeks, 1949.

Sample no.

Crushed rock percent eU I/
Heavy-mineral fraction 2/ Percent eU Concentration Ratio

Flint Creek (locations plotted on figure 3

Granite samples:

$\begin{array}{rrrr}3484 & 0.005 & 0.015 & 99: 1 \\ 3485 & .006 & .019 & 9: 1 \\ 3493 & .008 & .025 & 6: 1 \\ 3494 & .005 & .024 & 40: 1 \\ 3497 & .004 & .026 & 150: 1 \\ 3498 & .003 & .024 & 65: 1 \\ 3499 & .004 & .043 & 100: 1 \\ 3500 & .006 & .021 & 120: 1 \\ 3501 & .005 & .050 & 75: 1 \\ 3503 & .005 & .030 & 15: 1 \\ 3505 & .005 & .15 & 2,850: 1 \\ 3684 & .005 & .015 & 20: 1\end{array}$

Panned concentrates from granite wash:

3504

3506

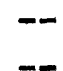

$-$
0.75

.31
$5,000: 1$

$8,200: 1$

Panned concentrates from creek gravels:

$\begin{array}{rrrr}3478 & -- & 0.11 & 1,250: 1 \\ 3481 & -- & .12 & 650: 1 \\ 3482 & -- & .224 & 1,450: 1 \\ 3486 & -- & .70 & 1,000: 1 \\ 3487 & -- & .025 & 2,700: 1 \\ 3488 & -- & .26 & 1,100: 1 \\ 3490 & -- & .62 & 680: 1 \\ 3492 & -- & .02 & 640: 1 \\ 3496 & -- & .93 & 1,600: 1 \\ 3507 & -- & 1.63 & 3,800: 1 \\ 3508 & -- & .46 & 4,200: 1 \\ 3509 & -- & .64 & 3,700: 1 \\ 3645 & -- & .065 & 1,250: 1 \\ 3687 & -- & .20 & 4,500: 1\end{array}$

1/ eU - equivalent uranium

2) That greater than 2.8 specific gravity 
-

-

• 
Table 2.--Data on samples from the vicinity of the granite on upper Flint and Monument Creeks, 1949--(Continued).

Monument Creek (locations plotted on figure 3)

Rumned from creek gravels:

3511

3512

3513

3515

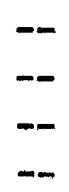

0.086

.001

.002

.14
High

Do. 290: 1

9,000:1 
-

•

• 
The radioactivity of the granite on upper Flint Creek and of the placers and wash derived from the granite is due chiefly to a uraniferous thorium silicate, tentatively identified as uranothorite, although the heavy fractions also contain much sphene, allanite, and zircon, which also contribute to the total radioactivity of the samples because they contain radioactive elements as impurities. Magnetite and ilmenite are also found in the heavy-mineral fractions.

The uranothorife(?) is dark green with a vitreous to dull luster. It is isotropic and has an index of refraction near 1.86. Following is a spectrographic analysis on selfeted grains from sample 3507 , the heavy-mineral fraction of which contains 1.53 percent equivalent uranium by radiometric analyses and 8 percent of the uranothorite(?) as estimated by visual inspection.

\begin{tabular}{l} 
Over 10 percent \\
\hline $\begin{array}{l}\text { thorium } \\
\text { silicon }\end{array}$ \\
$0.1-1.0$ percent \\
\hline $\begin{array}{l}\text { bismuth } \\
\text { cobalt } \\
\text { iron } \\
\text { tin }\end{array}$ \\
$0.01-0.1$ percent \\
\hline $\begin{array}{l}\text { aluminum } \\
\text { cerium } \\
\text { copper } \\
\text { magnesium } \\
\text { molybdenum } \\
\text { potassium } \\
\text { silver } \\
\text { sodium }\end{array}$
\end{tabular}

In addition to the above elements the mineral contains 8 a 2 percent uranium (determined chemically). Phair and Shimamoto (1952, p.662) show the thorium 
-

-

0 
content as 56.6 percent.

Analytical spectrographic analyses on what is apparently the same mineral from other samples (no. 3496 from Flint Creek, and no. 3477 from Birch Creek) show yttrium(?) as a minor constituent. The samples from Monument Creek $(0.032$ percent equivalent uranium) and Flint Creek ( 0.43 percent equivalent uranium) obtained before 1949 contain a green uraniferous thorium-yttrium silicate which was tentatively identified prior to this study as yttriftite. It is likely, however, that this mineral is the uranothorite(?) discussed above.

The uranothorite(?) and the other radioactive minerals mentioned above are disseminated accessory minerals of the granite, which is typically coarse-grained and porphyritic. No zones of high concentration were found. The uranothorite(?) appears to be less abundant in a minor fine-grained facies of the granite than in the large mass of coarse-grained rock.

\section{Poorman area}

Data on placer concentrates from the Poorman area (fig. 1) available for study prior to 1949 are summarized below.

Creek

Poorman Creek

Solomon Creek

Flat Creek

Moose Creek

Tamarack Creek

Spruce Creek
No. of

concentrates

5

3

1

1

1
Range in equivalent uranium content (percent)

$$
\begin{aligned}
& 0.000-0.006 \\
& .002-.056 \\
& .001 \\
& .000 \\
& .001 \\
& .004
\end{aligned}
$$

From this summary it appears that the only radioactivity of significance in concentrates from the Poorman area is in the samples from Solomon Creek. The most radio- 
-

-

- 
active sample came from the uppeipart of the creek. However, radiometric traversing in the upper valley of Solomon Creek and along adjacent divides failed to detect any significant radioactivity. Mineralogic study of the placer concentrate from Solomon Creek showing the greatest radioactivity $(0.056$ percent equivalent uranium) found that the radioactivity there is due to a uraniferous mineral of the spinel group. Qualitative spectrographic analysis of the mineral shows aluminum, chromium, iron, magnesium, titanium, and rare earths as major constituents.

\section{SUMMARY AND CONCLUSIONS}

Twö small bodies of granite in the vicinity of Long in the Ruby-Poorman district contain an average of 0.005 percent equivalent uranium. Although the radioactivity is due chiefly to a uraniferous thorium silicate, tentatively identified as uranothorite, radioactive allanite, hematite, sphene, and zircon also contributed to the total radioactivity.

Radiometric tests in the vicinity of a silver-lead lode 12 miles south of Ruby found no anomalous radiation at that locality. Search for the bedrock source of a radioactive spinel previously found in placers on Solomon Creek in the Poorman area was unsuccessful.

It is concluded from this investigation that there is little likelihood of finding uranium deposits of commercial grade in the Ruby-Poorman district. It should be noted, however, that much of the district is heavily covered with vegetation and alluvium, which prevents the satisfactory use of portable survey meters to detect radiation. 
-

- 


\section{LITERATURE CITED}

Brown, J. S., 1926, Silver-lead prospects near Ruby (Alaska): U. S. Geol. Survey Bull. 783-D, pp. 145-150.

Eakin, H. M., 1914, The Iditarod-Ruby region, Alaska: U. S. Geol. Survey Bull. 578. 631. , 1916, The Yukon-Koyukuk region, Alaska: U. S. Geol. Survey Bull.

Maddren, A. G., 1910, The Innoko gold placer district, Alaska: U. S. Geol. Survey Bull. 410 .

Mertie, J. B., Jr., 1936, Mineral deposits of the Ruby-Kuskokwim region (Alaska): U. S. Geol. Survey Bull. 864-C, pp. 115-255.

Mertie, J. B., Jr., and Harrington, G. L., 1924, The Ruby-Kuskokwim region, Alaska: U. S. Geol. Survey Bull. 754.

Phair, George, and Shimamoto, Kiyoko Onoda, 1952, Hydrothermal uranothorite in fluorite breccias from the Blue Jay mine, Jamestown, Boulder County, Colorado: American Mineralogist, vol. 37, no. 7, pp. 659-666. 